\title{
Antimicrobial activity of onion and ginger against two food borne pathogens Escherichia coli and staphylococcus Aureus
}

\begin{abstract}
Antimicrobial properties of phytochemicals extracted from onion (Allium cepa) and ginger (Zingiber officinale) were evaluated against Escherichia coli and Staphylococcus aureus, two common food borne pathogens. They were tested using minimum inhibitory concentration, minimum bactericidal concentration disc diffusion and agar wells diffusion. Onion showed good antimicrobial properties against S.aureus with an inhibition zone of $28 \mathrm{~mm}$ but was not all that effective against E.coli. Ginger showed very poor antimicrobial properties against either of the organisms. S.aureus was shown to be more susceptible to the phytochemicals than E.coli.
\end{abstract}

Keywords: Escherichia coli; Staphylococcus aureus; Enterotoxins
Volume I Issue 4 - 2015

\author{
Marsunn Ortiz \\ HP Science and technology Centennial College, Canada
}

Correspondence: Marsunn Ortiz, HP Science and technology Centennial College, 755 Morningside Ave, Scarborough, ON MIC, Canada, Tel 647-667-5484,

Email marsunn_ortiz@yahoo.com

Received: August 30, 2015 | Published: November 30, 2015

\section{Objective and purpose}

The purpose of this project was to investigate the antimicrobial effect of phytochemicals extracted from onion and ginger (fresh and boiled) at different concentrations, against Escherichia coli and Staphylococcus aureus using different methods (MIC, MBC, Disk and well diffusion). This project was chosen because onion and ginger are very common spices and have been claimed to contain several antimicrobial agents.

\section{Hypothesis}

i. Escherichia coli are more resistant to Staphylococcus aureus against chemical agents because it contains an outer membrane composed of lipopolysaccharide and protein which makes its membrane less permeable.

ii. Raw spice extract is more potent than the boiled spice extract.

\section{Introduction}

Food borne disease is gradually becoming a serious risk to public health with the number of cases increasing yearly. ${ }^{1}$ The cause is determined to be from microorganisms, people become infected by either eating food infected with microbes or intoxicated with enterotoxins produced from microbes. Proper control of microbes and effective sanitation will help to reduce the rate at which people become sick from eating food. Spices in general show both antimicrobial and antioxidant characteristics, inhibiting the growth of bacteria and other pathogenic microbes. ${ }^{1}$ Scientists in the past have conducted numerous experiments testing food borne pathogens with phytochemicals extracted from the spices. ${ }^{2}$ The antimicrobial properties of active compounds extracted from spices and other plants in general based on recent findings have shown to affect the behavior of pathogenic bacteria and fungi in the agro food and medicinal sector. ${ }^{1}$ This study investigates the antimicrobial activity of phytochemicals extracted from onion (Allium cepa) and ginger (Zingiber officinale) against E.coli and S.aureus using; Minimum inhibitory concentrations (MIC),
Minimum bactericidal concentrations (MBC), and disc and agar well diffusion.

\section{Onion and ginger}

Onion has been revered throughout time not only for its culinary use, but also for its therapeutic properties. Consumption of onion is beneficial to human health as scientific studies show onion contains polyphenol molecules or phytonutrients which includes flavonoids, tannins as well as allicin which possess antioxidant and antimicrobial properties. ${ }^{3}$ The main antimicrobial agent in onion isquercetin and allicin (thio-2-propene-1-sulfinic acid-5-allyl-esters), quercetin binds to the bacteria DNA gyrase while allicin inhibits certain thiol containing enzymes in the microorganisms by the rapid reaction of thiosulfinates. ${ }^{4}$

On the other hand, ginger has a long tradition of being very effective in alleviating symptoms of gastrointestinal distress. ${ }^{3}$ Ginger can also be used as herbal medicine, and modern scientific research has revealed that ginger possesses numerous therapeutic properties that are similar to onion, including antioxidant effects, an ability to inhibit the formation of inflammatory compounds, and direct antiinflammatory effects. ${ }^{1}$ The main antimicrobial agent is gingerol a naturally occurring phenol which disrupts the cell wall of bacteria causing cytoplasmic leakage. ${ }^{5}$

\section{Mininum inhibitory concentration and mininum bacteriacidal concentration}

Minimum inhibitory concentrations (MIC) is the lowest concentration of any antibacterial substance that prevents or inhibits the growth of a particular pathogen after an overnight incubation period while minimum bacterial concentration (MBC) is the lowest antibacterial concentration that kills the pathogen after an overnight incubation period of about 24-48hours. ${ }^{6}$ Minimum inhibitory concentrations (MIC) are regarded as the standard for determining the susceptibility of organisms to antimicrobials. ${ }^{6}$ 


\section{Disc and agar well diffusion}

The principle behind disc diffusion is relatively simple and easy to carry out, it involves an antibacterial impregnated disk placed on an agar previously inoculated with the test bacteria, when the disc picks up moisture the antibiotic diffuses outward through the agar producing an antibiotic concentration which produces zones of inhibition, the more susceptible the bacteria is to the antibiotic the greater the size of the zones. ${ }^{7}$ The principle behind the agar well diffusion is similar to that of disc diffusion, wells uare bored into in the plate previously inoculated with the test bacteria and even volumes of the various antimicrobial agents are put into the wells which diffuse onto the agar and produces zones of inhibition. ${ }^{7}$

\section{Escherichia coli}

Escherichia coli is a Gram-negative, straight rod bacteria of about $1.1-1.5 \mu \mathrm{m}$ by $2.0-6.0 \mu \mathrm{m}$ occurring either singly or in pairs. They belong to the class Proteobacteria, the order Enterobacteriales, the family Enterobacteriaceae and the genus Escherichia. ${ }^{7}$ They are motile by peritrichous flagella and facultatively anaerobic having both a respiratory and a fermentative type of metabolism (Bergey, 2000). Biochemically they are oxidase negative, catalase positive, methyl red positive, Voges-Proskauer negative and usually citrate negative. ${ }^{8}$ E.coli occurs as normal flora in the lower part of the intestine, optimal growth for is about 37 degrees but they are known to grow at temperatures of about 44.5 degrees. ${ }^{9}$ E.coli strains containing enterotoxins are known to cause diarrheal diseases due to their invasive and colonization characteristics, they are also a major cause of urinary tract infections and nosocomial infections including septicemia and meningitis. ${ }^{9}$ When plated on differential media such as FC agar and Eosin methylene blue agar at 44.5 and 35 degrees respectively for about 48 hours they produce dark green metallic sheen colonies, when plated on MaCconkey agar at 35degrees they give pink colonies due to the fermentation of lactose. ${ }^{10}$ E.coli was used for this study because it is a bacterial food borne pathogen responsible for infecting hundreds of people each year.

\section{Staphylococcus aureus}

Staphylococcus aureus is a gram-positive cocci bacterium that is a member of the Firmicutes group. It belongs to the class Cocci, order Bacillales, family Staphylococcaceae and genus Staphylococcus. ${ }^{7}$ The cells are spherical about $0.5-1.5 \mu \mathrm{m}$ in diameter and in clusters or pairs. They are non-motile non-sporing facultatively anaerobic with both respiratory and fermentative mechanisms. ${ }^{8}$ Colonies are usually white and cream on general purpose agar such as TSA or yellow on differential media such as MSA. Biochemically they are catalase positive and can grow in about $10 \% \mathrm{NaCl}$ with an optimum temperature of about 30-37degrees. ${ }^{9}$ They are mainly associated with the skin and mucus membrane of warm blooded animal and serves as an indicator of nasal contamination in foods. They are known as opportunistic pathogen in humans causing diarrhea by producing extracellular toxins. ${ }^{9}$ S.aureus is an important food borne pathogen causing several incidents of food poisoning which leads to diarrhea.

\section{Media}

MacConkey agar: MacConkey Agar is used for the detection and enumeration of gram negative bacteria based on their ability to ferment lactose. Bile salts and crystal violent serves as the selective agent while phenol red is the indictor. E.coli a lactose fermenter grows extremely well on MAC producing pink colonies with red zones. ${ }^{10}$
MR-VP BROTH: MR-VP Medium and MR-VP Broth (Methyl RedVoges Proskauer Medium/Broth, are used for the differentiation of bacteria by means of the methyl red and Voges-Proskauer reactions. ${ }^{11}$

Simmons citrate agar: Simmons Citrate Agar is used from differentiating bacteria which can utilize citrate as the sole source of carbon and inorganic ammonium salt as the sole source of Escherichia coli either do not grow at all on this medium, or grow so sparsely that no change in reaction is apparent as the media still remains green. Sodium Citrate is the sole source of carbon in this medium. Magnesium Sulphate is a cofactor for a variety of metabolic reactions. Bromthymol Blue is the $\mathrm{pH}$ indicator. ${ }^{12}$

Mannitol salt agar: Mannitol Salt Agar is highly selective and used to isolate coagulase positive Staphylococcus aureus by inhibiting growth of most other bacteria with a high salt concentration of about $7.5 \%$ Sodium Chloride. Bacteria that grow in the presence of a high salt concentration and ferment mannitol to produce acid products, turning the Phenol Red $\mathrm{pH}$ indicator from red to yellow. Staphylococcus aureus ferment mannitol and form yellow colonies with yellow zones. (Neogen 2015).

Mueller hinton broth and agar: Mueller Hinton Broth and Agar are used for performing antibiotic susceptibility tests (MIC, MBC) using a single disk of high concentration. The medium provides excellent growth for most non-fastidious pathogens due to its low concentration of sulphonamide. ${ }^{13}$

Tryptic Soy Broth: Tryptic Soy Broth is a general purpose medium. Tryptic Soy Broth is used for the preparation of inoculum used in antibiotic tests. Casein and Soybean Meal serves as the source of nitrogen in TSB. Dextrose is the carbon source which enables the organism to grow. Osmotic balance and buffering agent are maintained by Sodium Chloride and Dipotassium Phosphate. Most clinical tested microbes grow extremely on TSB. ${ }^{14}$

Recent research conducted on the antimicrobial effect of ginger and onion showed weak to medium antibacterial properties. ${ }^{1}$ The author used agar well diffusion to determine the zones of inhibition. Also results according to Onyeagba et al. ${ }^{15}$ also showed both ginger and onion to have significant antimicrobial properties.

\section{Materials}

\section{Bacteria}

i. Escherichia coli ATCC 25922 obtained from Prep Room.

ii. Staphylococcus aureus ATCC 25923 obtained from Prep Room.

\section{Spices}

i. Onion (Allium cepa) obtained from Food Basic along Neilson Road.

ii. Ginger (Zingiber officinale) obtained from Food Basic along Neilson Road.

\section{Media}
i. MacConkey Agar
ii. Mannitol Salt Agar
iii. Mueller Hinton Agar
iv. Simmon Citrate Agar (SIM) 
v. Tryptic Soy Broth

vi. Mueller Hinton Broth

vii. MR-VP Broth

viii. Coagulase

\section{Supplies and equipment}

i. Blender

ii. Hot plate

iii. Chopping Board and Knife.

iv. Mortar, Pestle and cheese cloth

v. Antimicrobial Disks

vi. Ampicillin disks obtained from the prep room

vii. Ciprofloxacin disks obtained from the prep room

viii. Hydrogen peroxide for Catalase test

ix. Phosphate

\section{Methods}

\section{Sample collection}

100 grams of onion and 100 grams of ginger were purchased from Food basic store along Neilson road.

\section{Restreaking on selective media}

A colony of E.coli obtained from the prep room was streaked on a MaCconkey agar plate and incubated at 35degrees for 48hours; the same was done with a colony of S.aureus on an MSA plate and incubated at 35 degrees for 48 hours. Restreaking on selective was carried out regularly at the beginning of every week in other to have a fresh supply of bacterial colonies needed for the experiment. It was used for bacteriological analysis and biochemical characterization.

\section{Morphological Characterization}

The isolated microbes from both Mac cultures and MSA cultures were characterised morphologically on the basis of simple gram staining.

\section{Biochemical characterization}

The isolates were characterised by biochemical tests using citrate utilization test, Methyl red test and Voges Proskauer test for E.coli and catalase and coagulase test for S.aureus, this was carried out in order to determine purity of tested micro-organism. A single colony of E.coli was inoculated on citrate agar slant and MR-VP broth for 48hours and incubated at 35degrees after which two drops of MR reagent and VP reagents were added. Also, a colony of S.aureus was placed on a microscope slide and three drops of hydrogen peroxide was added onto it and viewed for the formation of gas bubbles which indicates the presence of catalase. Coagulase test was also carried out on the same colony of S.aureus, which was inoculated and incubated for 48 hours at 35 degrees. Negative controls were also carried out by incubating the media used without any inoculate for 48 hours at 35degrees.

\section{Preparation of Inoculate}

Isolated colonies of E.coli and S.aureus from the Mac and MSA cultures were inoculated in a test tube containing $9 \mathrm{ml}$ of TSB and incubated at 35 degrees for 48 hours. The overnight cultures obtained from the tubes were used to determine the minimum inhibitory concentration of onion and ginger extracts.

\section{Preparation of onion and ginger extracts}

The onion and ginger obtained, was cleaned and washed using sterile distilled water. Using a disinfected knife and chopping board the samples were cut into smaller pieces, crushed in a mortar using a pestle and liquefied in a blender. The extracts were then sieved through a sterile cheese cloth into a sterile Erlenmeyer flask; this extract was considered as the $100 \%$ raw extract. The same procedure was repeated and the extract was boiled in a sterile conical flask for 5minutes, this was thus considered as the $100 \%$ boiled extract.

\section{Determination of Minimum Inhibitory Concentration (MIC)}

$0 \mathrm{ml}, 1 \mathrm{ml}, 2 \mathrm{ml}, 3 \mathrm{ml}, 4 \mathrm{ml}$, and $5 \mathrm{ml}$ of Mueller Hilton broth was pipetted into different sterile test tubes. After which $10 \mathrm{ml}$, $9 \mathrm{ml}, 8 \mathrm{ml} .7 \mathrm{ml}, 6 \mathrm{ml}$ and $5 \mathrm{ml}$ of each extract was added into the corresponding tubes containing $0 \mathrm{ml}, 1 \mathrm{ml}, 2 \mathrm{ml}, 3 \mathrm{ml}, 4 \mathrm{ml}$ and $5 \mathrm{ml}$ of Mueller Hinton broth. This represented $100 \%, 90 \%, 80 \%, 70 \%$, $60 \%$ and $50 \%$ concentration of each extract. Using a sterile Pasteur pipette 2 drops of each culture was added into each tube respectively. This was done for both the raw and boiled extract for both onion and ginger for each organism and thus a total of 48 tubes was incubated at 35 degrees for 48 hours and observed for growth by turbidity.

Negative controls were also set up using $5 \mathrm{ml}$ of both the raw and boiled extract for onion and ginger and incubated at 35 degrees for 48 hours. Media controls were also set up using $10 \mathrm{ml}$ of Mueller Hinton broth and incubated at 35 degrees for 48 hours. The purpose of the control was to determine the presence of growth and no growth, to determine if the media was contaminated and to eliminate false positives.

\section{Determination of Minimum Bactericidal Concentration (MBC)}

A loop-full from each tube containing the different concentrations of both onion and ginger extract with the respective microbes was plated onto a plate containing Mueller Hilton agar. Each tube was plated onto the same plate with different partitions indicating concentration. In all a total of 8 plates one for each microbe and spice (boiled and raw) was incubated for 48 hours at 35 degrees and observed for growth on the surface of the agar.

Negative controls were also done by incubating an empty plate of Mueller Hinton agar for 48 hours at 35 degrees. This was done to check sterility of media.

\section{Disc diffusion and agar well diffusion}

Each tube containing overnight cultures of E.coli and S.aureus were diluted in phosphate buffer to a concentration of $2.5 \mathrm{Mcfarland}$. After which $0.1 \mathrm{ml}$ of each culture was spread across the surface of the plates containing $\mathrm{MH}$ agar. 24sterile discs were used for each organism and each spice which was impregnated in various concentrations ranging from $100-50 \%$ and placed on the surface of the agar which 
was incubated for 35 degrees at 48 hours and examined for zones of inhibition. Inhibition zones less than or equal to $7 \mathrm{~mm}$ were considered to have no antimicrobial effect.

Positive controls were also set up using ampicillin and ciprofloxacin disc which was placed onto the surface of the agar and incubated for 48 hours at 35 degrees. Media controls were also set up by incubating a plate of $\mathrm{MH}$ agar for 48 hours at 35degrees. Agar well diffusion followed the same principle as disc diffusion the only difference been well were bored in the agar already inoculated with the test microbes and different concentrations of spice extracts were placed into the wells which was incubated for 48 hours and 35degrees.

\section{Results}

\section{Biochemical characterisation}

The following tables show the biochemical characterisation of the two isolates used. Simmon citrate agar and MR-VR broth were used for E.coli, inoculated and were incubated for 48hours at 35degrees, while the coagulase test was used for S.aureus and was also incubated for 48 hours at 35 degrees. The catalase test was also carried out on S.aureus (Table 1).

Citrate utilization test showed E.coli does not utilize citrate due to the media remaining unchanged this is a typical E.coli reaction. When the MR reagent was added a bright red color appeared this is regarded as a positive result while when the VP reaction was added there was no change, this is regarded as a negative result which is typical to E.coli (Table 2).

Coagulase test was positive due to clot which showed S.aureus produces coagulase and the presence of gas bubbles also indicated that the catalase test was positive.

\section{Morphological Characterisation}

The following table shows the morphological characterisation and gram reaction of E.coli and S.aureus (Table 3). Morphological characterisation of E.coli was characterised by the presence of red rod shaped cells in random order and purple cocci shaped cells in clusters for S.aureus with indicates a typical morphological characterisation for both cells.

\section{Minimum inhibitory concentration}

The following tables show the result for the Minimum Inhibitory Concentration of both the raw and boiled extract of both species which was diluted in Mueller Hinton broth to get specific concentrations, inoculated with overnight culture of E.coli and S.aureus and incubated for 48hours at 35degrees (Table 4).

Due to the nature of the extracts the negative controls were used to determine the presence and absence of growth by comparing it with the inoculated tubes. The Negative controls showed no growth in them (Table 5).

The presence of growth was identified by the turbidity of the tubes and the presence of a whitish pellicle on the surface of the tubes. Also the presence of no growth was identified by the similarity of the tubes to the negative controls (Table 6).

The presence of growth was identified by the turbidity of the tubes and the presence of a whitish pellicle on the surface of the tubes. Also the presence of no growth was identified by the similarity of the tubes to the negative controls (Table 7).

Due to the nature of the extracts the negative control were used to determine the presence and absence of growth by comparing it with the inoculated tubes. The Negative controls showed no growth in them (Table 8).

The presence of growth was identified by the turbidity of the tubes and the presence of a whitish pellicle on the surface of the tubes. Also the presence of no growth was identified by the similarity of the tubes to the negative controls (Table 9).

The presence of growth was identified by the turbidity of the tubes and the presence of a whitish pellicle on the surface of the tubes. Also the presence of no growth was identified by the similarity of the tubes to the negative controls.

\section{Minimum bactericidal concentration}

The following tables show the result for the minimum bactericidal concentration of all tubes inoculated, a loopful was transferred unto partitioned sections on a plate of Mueller Hilton agar and incubated for 35 degrees at 48 hours (Table 10).

MBC results showed that $80 \%$ concentration of raw onion was capable of killing the E.coli cells. The ginger extract on the other hand was not capable of killing the cells (Table 11).

MBC results showed that $70 \%$ concentration of raw onion was capable of killing the S.aureus cells. The ginger extract on the other hand was not capable of killing the cells. MBC for boiled onion and ginger extract (Table 12). MBC results showed both the onion and ginger extract was not capable of killing the cells (Table 13).

\section{Disc diffusion}

The following tables shows the results for the antimicrobial activity of the spice extract against E.coli and S.aureus measured as the diameter of growth inhibition using impregnated discs with different concentration of the spice extracts which were diluted in different volumes of distilled sterile water. Positive controls were also carried out using ampicillin and ciprofloxacin disc on inoculated plates of E.coli and S.aureus incubated for 48 hours at 35 degrees (Table 14) $\&$ (Table 15). The result showed onion to have good antimicrobial properties S.aureus but also showed ginger having no antimicrobial properties against S.aureus (Table 16). The result showed boiled spice extract to have no antimicrobial properties against both organisms (Table 17).

\section{Agar well diffusion}

The following tables shows the results for the antimicrobial activity of the spice extract against E.coli and S.aureus measured as the diameter of growth inhibition from the wells bored in the agar, each well contained a different concentrations of spice extracts. The plates were incubated for 48 hours at 35 degrees. The diameter of the wells were $7 \mathrm{~mm}$ (Table 18). The zones of inhibition gotten above showed both onion and ginger to have no antimicrobial activity on E.coli (Table 19). The result showed onion to have fairly good antimicrobial properties S.aureus but also showed ginger having no antimicrobial properties against S.aureus. 
Table I Biochemical characterisation results of $E$. coli using Simmon citrate agar to test for citrate utilization and MR-VR broth inoculated and incubated 48 hours at 35 degrees

\begin{tabular}{llll}
\hline Biochemical tests & Citrate test & Mr reagent & Vp reagent \\
\hline Reactions & Green medium & Bright red (positive) & No red color (Negative)
\end{tabular}

Table 2 Biochemical characterisation results of S. aureus using coagulase which was inoculated and incubated for 48 hours at 35 degrees and catalase test using Hydrogen Peroxide

\begin{tabular}{lll}
\hline Biochemical tests & Coagulase & Catalase \\
\hline Reactions & Clot formation & Bubbles
\end{tabular}

Table 3 Morphological characterisation of E. coli and S. aureus using simple gram staining and viewed under a microscope at

\begin{tabular}{lll}
\hline Bacteria & E. coli & S. aureus \\
\hline Gram reactions \& morphology & Negative, Rod shaped in a random order & Positive Cocci in clusters
\end{tabular}

Table 4 Negative controls of raw extracts from onion and ginger which was incubated at 35 degrees for 48 hours

\begin{tabular}{lll}
\hline Controls & Onion & Ginger \\
\hline Description & Slightly clear with particles settled at the bottom & Yellowish slightly clear solution with particles settled at the bottom. \\
\hline
\end{tabular}

Table 5 MIC of various concentrations of raw onion and ginger extract against inoculated strains of E. coli which was incubated at 35 degrees for 48 hours

\begin{tabular}{|c|c|c|c|c|c|c|}
\hline Onion conc & $100 \%$ & $90 \%$ & $80 \%$ & $70 \%$ & $60 \%$ & $50 \%$ \\
\hline $\begin{array}{l}\text { Observation of } \\
\text { Tubes }\end{array}$ & $\begin{array}{l}\text { Slightly clear } \\
\text { with particles } \\
\text { settled at the } \\
\text { bottom }\end{array}$ & $\begin{array}{l}\text { Slightly clear } \\
\text { with particles } \\
\text { settled at the } \\
\text { bottom }\end{array}$ & $\begin{array}{l}\text { Slightly clear } \\
\text { with particles } \\
\text { settled at the } \\
\text { bottom }\end{array}$ & $\begin{array}{l}\text { Slightly clear } \\
\text { with particles } \\
\text { settled at the } \\
\text { bottom }\end{array}$ & $\begin{array}{l}\text { Slightly clear } \\
\text { with particles } \\
\text { settled at the } \\
\text { bottom }\end{array}$ & $\begin{array}{l}\text { Turbid with } \\
\text { particles settled at } \\
\text { the bottom }\end{array}$ \\
\hline Ginger conc & $100 \%$ & $90 \%$ & $80 \%$ & $70 \%$ & $60 \%$ & $50 \%$ \\
\hline $\begin{array}{l}\text { Observation of } \\
\text { Tubes }\end{array}$ & $\begin{array}{l}\text { Whitish pellicle } \\
\text { on the surface of } \\
\text { the tubes. }\end{array}$ & $\begin{array}{l}\text { Whitish pellicle } \\
\text { on the surface of } \\
\text { the tubes. }\end{array}$ & $\begin{array}{l}\text { Whitish pellicle } \\
\text { on the surface of } \\
\text { the tubes. }\end{array}$ & $\begin{array}{l}\text { Whitish pellicle } \\
\text { on the surface of } \\
\text { the tubes. }\end{array}$ & $\begin{array}{l}\text { Whitish pellicle } \\
\text { on the surface of } \\
\text { the tubes. }\end{array}$ & $\begin{array}{l}\text { Whitish pellicle } \\
\text { on the surface of } \\
\text { the tubes. }\end{array}$ \\
\hline
\end{tabular}

Table 6 MIC of various concentrations of raw onion and ginger extract against inoculated strains of S. aureus which was incubated at 35 degrees for 48 hours.

\begin{tabular}{|c|c|c|c|c|c|c|}
\hline Onion conc & $100 \%$ & $90 \%$ & $80 \%$ & $70 \%$ & $60 \%$ & $50 \%$ \\
\hline $\begin{array}{l}\text { Observation of } \\
\text { tubes }\end{array}$ & $\begin{array}{l}\text { Slightly clear } \\
\text { with particles } \\
\text { settled at the } \\
\text { bottom }\end{array}$ & $\begin{array}{l}\text { Slightly clear } \\
\text { with particles } \\
\text { settled at the } \\
\text { bottom }\end{array}$ & $\begin{array}{l}\text { Slightly clear } \\
\text { with particles } \\
\text { settled at the } \\
\text { bottom }\end{array}$ & $\begin{array}{l}\text { Slightly clear } \\
\text { with particles } \\
\text { settled at the } \\
\text { bottom }\end{array}$ & $\begin{array}{l}\text { Slightly clear } \\
\text { with particles } \\
\text { settled at the } \\
\text { bottom }\end{array}$ & $\begin{array}{l}\text { Turbid with } \\
\text { particles settled at } \\
\text { the bottom }\end{array}$ \\
\hline Ginger conc & $100 \%$ & $90 \%$ & $80 \%$ & $70 \%$ & $60 \%$ & $50 \%$ \\
\hline $\begin{array}{l}\text { Observation of } \\
\text { tubes }\end{array}$ & $\begin{array}{l}\text { Yellow liquid } \\
\text { with particles } \\
\text { settled at the } \\
\text { bottom }\end{array}$ & $\begin{array}{l}\text { Yellow liquid } \\
\text { with particles } \\
\text { settled at the } \\
\text { bottom. }\end{array}$ & $\begin{array}{l}\text { Whitish pellicle } \\
\text { on the surface of } \\
\text { the tubes. }\end{array}$ & $\begin{array}{l}\text { Whitish pellicle } \\
\text { on the surface of } \\
\text { the tubes. }\end{array}$ & $\begin{array}{l}\text { Whitish pellicle } \\
\text { on the surface of } \\
\text { the tubes }\end{array}$ & $\begin{array}{l}\text { Whitish pellicle on } \\
\text { the surface of the } \\
\text { tubes. }\end{array}$ \\
\hline
\end{tabular}

Table 7 Negative controls of boiled extracts from onion and ginger which was incubated at 35degrees for 48hours

\begin{tabular}{lll}
\hline Controls & Onion & Ginger \\
\hline Description & Slightly clear with particles settled at the bottom & Yellowish slightly clear solution with particles settled at the bottom. \\
\hline
\end{tabular}


Table 8 MIC of various concentrations of boiled onion and ginger extract against inoculated strains of E. coli which was incubated at 35 degrees for 48 hours

\begin{tabular}{|c|c|c|c|c|c|c|}
\hline Onion conc & $100 \%$ & $90 \%$ & $80 \%$ & $70 \%$ & $60 \%$ & $50 \%$ \\
\hline $\begin{array}{l}\text { Observation of } \\
\text { Tubes }\end{array}$ & $\begin{array}{l}\text { Turbid with } \\
\text { particles settled } \\
\text { at the bottom }\end{array}$ & $\begin{array}{l}\text { Turbid with } \\
\text { particles settled } \\
\text { at the bottom }\end{array}$ & $\begin{array}{l}\text { Turbid with } \\
\text { particles settled } \\
\text { at the bottom }\end{array}$ & $\begin{array}{l}\text { Turbid with } \\
\text { particles settled } \\
\text { at the bottom }\end{array}$ & $\begin{array}{l}\text { Turbid with } \\
\text { particles settled } \\
\text { at the bottom }\end{array}$ & $\begin{array}{l}\text { Turbid with } \\
\text { particles settled } \\
\text { at the bottom }\end{array}$ \\
\hline Ginger conc & $100 \%$ & $90 \%$ & $80 \%$ & $70 \%$ & $60 \%$ & $50 \%$ \\
\hline $\begin{array}{l}\text { Observation of } \\
\text { Tubes }\end{array}$ & $\begin{array}{l}\text { Whitish pellicle } \\
\text { on the surface of } \\
\text { the tubes }\end{array}$ & $\begin{array}{l}\text { Whitish pellicle } \\
\text { on the surface of } \\
\text { the tubes }\end{array}$ & $\begin{array}{l}\text { Whitish pellicle } \\
\text { on the surface of } \\
\text { the tubes }\end{array}$ & $\begin{array}{l}\text { Whitish pellicle } \\
\text { on the surface of } \\
\text { the tubes }\end{array}$ & $\begin{array}{l}\text { Whitish pellicle } \\
\text { on the surface of } \\
\text { the tubes }\end{array}$ & $\begin{array}{l}\text { Whitish pellicle } \\
\text { on the surface of } \\
\text { the tubes }\end{array}$ \\
\hline
\end{tabular}

Table 9 MIC of various concentrations of boiled onion and ginger extract against inoculated strains of S. aureus which was incubated at 35 degrees for 48 hours

\begin{tabular}{|c|c|c|c|c|c|c|}
\hline Onion conc & $100 \%$ & $90 \%$ & $80 \%$ & $70 \%$ & $60 \%$ & $50 \%$ \\
\hline $\begin{array}{l}\text { Observation of } \\
\text { Tubes }\end{array}$ & $\begin{array}{l}\text { Turbid with } \\
\text { particles settled } \\
\text { at the bottom }\end{array}$ & $\begin{array}{l}\text { Turbid with } \\
\text { particles settled } \\
\text { at the bottom }\end{array}$ & $\begin{array}{l}\text { Turbid with } \\
\text { particles settled } \\
\text { at the bottom }\end{array}$ & $\begin{array}{l}\text { Turbid with } \\
\text { particles settled } \\
\text { at the bottom }\end{array}$ & $\begin{array}{l}\text { Turbid with } \\
\text { particles settled } \\
\text { at the bottom }\end{array}$ & $\begin{array}{l}\text { Turbid with } \\
\text { particles settled } \\
\text { at the bottom }\end{array}$ \\
\hline Ginger conc & $100 \%$ & $90 \%$ & $80 \%$ & $70 \%$ & $60 \%$ & $50 \%$ \\
\hline $\begin{array}{l}\text { Observation of } \\
\text { Tubes }\end{array}$ & $\begin{array}{l}\text { Whitish pellicle } \\
\text { on the surface of } \\
\text { the tubes }\end{array}$ & $\begin{array}{l}\text { Whitish pellicle } \\
\text { on the surface of } \\
\text { the tubes }\end{array}$ & $\begin{array}{l}\text { Whitish pellicle } \\
\text { on the surface of } \\
\text { the tubes }\end{array}$ & $\begin{array}{l}\text { Whitish pellicle } \\
\text { on the surface of } \\
\text { the tubes }\end{array}$ & $\begin{array}{l}\text { Whitish pellicle } \\
\text { on the surface of } \\
\text { the tubes }\end{array}$ & $\begin{array}{l}\text { Whitish pellicle } \\
\text { on the surface of } \\
\text { the tubes }\end{array}$ \\
\hline
\end{tabular}

Table 10 MBC results of the various concentration of raw onion and ginger extract against E. coli, inoculated and incubated on Mueller Hilton agar for 35 degrees at 48 hours

\begin{tabular}{lllllll}
\hline Onion conc & $\mathbf{1 0 0} \%$ & $\mathbf{9 0 \%}$ & $\mathbf{8 0 \%}$ & $\mathbf{7 0 \%}$ & $\mathbf{6 0 \%}$ & $\mathbf{5 0 \%}$ \\
\hline Growth/no growth & No growth & No growth & Growth & Growth & Growth & Growth \\
Ginger conc & $\mathbf{1 0 0} \%$ & $\mathbf{9 0 \%}$ & $\mathbf{8 0}$ & $\mathbf{7 0 \%}$ & $\mathbf{6 0 \%}$ & $\mathbf{5 0 \%}$ \\
Growth/no growth & Growth & Growth & Growth & Growth & Growth & Growth \\
\hline
\end{tabular}

Table I I MBC results of the various concentration of raw onion and ginger extract against S. aureus, inoculated and incubated on Mueller Hilton agar for 35 degrees at 48 hours

\begin{tabular}{lllllll}
\hline Onion conc & $\mathbf{1 0 0 \%}$ & $\mathbf{9 0 \%}$ & $\mathbf{8 0} \%$ & $\mathbf{7 0 \%}$ & $\mathbf{6 0 \%}$ & $\mathbf{5 0 \%}$ \\
\hline Growth/no growth & No growth & No growth & No growth & No growth & Growth & Growth \\
Ginger conc & $\mathbf{1 0 0 \%}$ & $\mathbf{9 0 \%}$ & $\mathbf{8 0} \%$ & $\mathbf{7 0 \%}$ & $\mathbf{6 0 \%}$ & $\mathbf{5 0 \%}$ \\
Growth/no growth & Growth & Growth & Growth & Growth & Growth & Growth \\
\hline
\end{tabular}

Table 12 MBC results of the various concentration of boiled onion and ginger extract against S. aureus, inoculated and incubated on Mueller Hilton agar for 35 degrees at 48 hours

\begin{tabular}{lllllll}
\hline Onion conc & $\mathbf{1 0 0} \%$ & $\mathbf{9 0 \%}$ & $\mathbf{8 0 \%}$ & $\mathbf{7 0 \%}$ & $\mathbf{6 0 \%}$ & $\mathbf{5 0 \%}$ \\
\hline Growth/no growth & Growth & Growth & Growth & Growth & Growth & Growth \\
Ginger conc & $\mathbf{1 0 0 \%}$ & $\mathbf{9 0 \%}$ & $\mathbf{8 0 \%}$ & $\mathbf{7 0 \%}$ & $\mathbf{6 0 \%}$ & $\mathbf{5 0 \%}$ \\
Growth/no growth & Growth & Growth & Growth & Growth & Growth & Growth \\
\hline
\end{tabular}


Table 13 MBC results of the various concentration of boiled onion and ginger extract against E. coli, inoculated and incubated on Mueller Hilton agar for 35 degrees at 48 hours

\begin{tabular}{lllllll}
\hline Onion conc & $\mathbf{1 0 0 \%}$ & $\mathbf{9 0 \%}$ & $\mathbf{8 0 \%}$ & $\mathbf{7 0 \%}$ & $\mathbf{6 0 \%}$ & $\mathbf{5 0 \%}$ \\
\hline Growth/no growth & Growth & Growth & Growth & Growth & Growth & Growth \\
Ginger conc & $100 \%$ & $90 \%$ & $80 \%$ & $70 \%$ & $60 \%$ & $50 \%$ \\
Growth/no growth & Growth & Growth & Growth & Growth & Growth & Growth \\
\hline
\end{tabular}

TABLE I 4 Positive control using ampicillin and ciprofloxacin disc on plates containing E. coli and S. aureus incubated for 48 hours at 35 degrees

\begin{tabular}{ll}
\hline Ampicillin $(\boldsymbol{E}$. coli) & Ciprofloxacin $(\boldsymbol{E}$. coli) \\
\hline Zone: $21 \mathrm{~mm}$ & Zone: $45 \mathrm{~mm}$ \\
Ampicillin (S. aureus) & Ciprofloxacin (S. aureus) \\
Zone: $46 \mathrm{~mm}$ & Zone: $30 \mathrm{~mm}$. \\
\hline
\end{tabular}

The diameter of the disc was $7 \mathrm{~mm}$.

Table 14 Positive control using ampicillin and ciprofloxacin disc on plates containing E. coli and S. aureus incubated for 48 hours at 35 degrees

\begin{tabular}{ll}
\hline Ampicillin $(\boldsymbol{E}$. coli) & Ciprofloxacin $($ E. coli) \\
\hline Zone: $21 \mathrm{~mm}$ & Zone: $45 \mathrm{~mm}$ \\
Ampicillin (S. aureus) & Ciprofloxacin (S. aureus) \\
Zone: $46 \mathrm{~mm}$ & Zone: $30 \mathrm{~mm}$. \\
\hline
\end{tabular}

Table 15 Disc diffusion results for various concentrations of raw onion and ginger extract against E. coli on Mueller Hinton agar and incubated for 48hours and 35degrees

\begin{tabular}{lllllll}
\hline Onion Conc & $\mathbf{1 0 0 \%}$ & $\mathbf{9 0 \%}$ & $\mathbf{8 0} \%$ & $\mathbf{7 0 \%}$ & $\mathbf{6 0 \%}$ & $\mathbf{5 0 \%}$ \\
\hline Size of zone & $7 \mathrm{~mm}$ & $7 \mathrm{~mm}$ & $7 \mathrm{~mm}$ & $7 \mathrm{~mm}$ & $7 \mathrm{~mm}$ & $7 \mathrm{~mm}$ \\
Ginger Conc & $\mathbf{1 0 0 \%}$ & $\mathbf{9 0 \%}$ & $\mathbf{8 0} \%$ & $\mathbf{7 0} \%$ & $\mathbf{6 0} \%$ & $\mathbf{5 0 \%}$ \\
Size of zone & $7 \mathrm{~mm}$ & $7 \mathrm{~mm}$ & $7 \mathrm{~mm}$ & $7 \mathrm{~mm}$ & $7 \mathrm{~mm}$ & $7 \mathrm{~mm}$ \\
\hline
\end{tabular}

The zones of inhibition gotten above showed both onion and ginger to have no antimicrobial activity on E. coli.

Table 16 Disc diffusion results for various concentration of onion and ginger extract against a spread of S. aureus on Mueller Hilton Agar and incubated for 48 hours and 35 degrees

\begin{tabular}{lcccccc}
\hline Onion conc & $\mathbf{1 0 0} \%$ & $\mathbf{9 0} \%$ & $\mathbf{8 0} \%$ & $\mathbf{7 0} \%$ & $\mathbf{6 0 \%}$ & $\mathbf{5 0 \%}$ \\
\hline Size of zone & $28 \mathrm{~mm}$ & $27 \mathrm{~mm}$ & $25 \mathrm{~mm}$ & $24 \mathrm{~mm}$ & $23 \mathrm{~mm}$ & $20 \mathrm{~mm}$ \\
Ginger conc & $\mathbf{1 0 0 \%}$ & $\mathbf{9 0 \%}$ & $\mathbf{8 0} \%$ & $\mathbf{7 0} \%$ & $\mathbf{6 0 \%}$ & $\mathbf{5 0 \%}$ \\
Size of zone & $7 \mathrm{~mm}$ & $7 \mathrm{~mm}$ & $7 \mathrm{~mm}$ & $7 \mathrm{~mm}$ & $7 \mathrm{~mm}$ & $7 \mathrm{~mm}$ \\
\hline
\end{tabular}


Table 17 Disc diffusion results for boiled onion and ginger extract against a spread of S. aureus and E. coli incubated for 48 hours at 35 degrees

\begin{tabular}{ll}
\hline E. coli & S. aureus \\
\hline Onion $\mathbf{1 0 0 \%}$ & Onion $\mathbf{1 0 0 \%}$ \\
Zone $: 7 \mathrm{~mm}$ & Zone $: 7 \mathrm{~mm}$ \\
Ginger $\mathbf{1 0 0 \%}$ & Ginger $\mathbf{1 0 0 \%}$ \\
Zone: $7 \mathrm{~mm}$ & Zone: $7 \mathrm{~mm}$ \\
\hline
\end{tabular}

Table 18 Agar well diffusion results for various concentration of onion and ginger extract against a spread of E. coli on Mueller Hilton agar and incubated for 48hours and 35 degrees

\begin{tabular}{lcccccc}
\hline Onion Conc & $\mathbf{1 0 0 \%}$ & $\mathbf{9 0 \%}$ & $\mathbf{8 0 \%}$ & $\mathbf{7 0 \%}$ & $\mathbf{6 0 \%}$ & $\mathbf{5 0 \%}$ \\
\hline Size of zone & $7 \mathrm{~mm}$ & $7 \mathrm{~mm}$ & $7 \mathrm{~mm}$ & $7 \mathrm{~mm}$ & $7 \mathrm{~mm}$ & $7 \mathrm{~mm}$ \\
Ginger Conc & $\mathbf{1 0 0 \%}$ & $\mathbf{9 0 \%}$ & $\mathbf{8 0 \%}$ & $\mathbf{7 0 \%}$ & $\mathbf{6 0 \%}$ & $\mathbf{5 0 \%}$ \\
Size of zone & $7 \mathrm{~mm}$ & $7 \mathrm{~mm}$ & $7 \mathrm{~mm}$ & $7 \mathrm{~mm}$ & $7 \mathrm{~mm}$ & $7 \mathrm{~mm}$ \\
\hline
\end{tabular}

Table 19 Agar well diffusion results for various concentration of onion and ginger extract against a spread of S. aureus on Mueller Hilton agar and incubated for 48hours and 35degrees

\begin{tabular}{lllllll}
\hline Onion Conc & $\mathbf{1 0 0 \%}$ & $\mathbf{9 0 \%}$ & $\mathbf{8 0 \%}$ & $\mathbf{7 0 \%}$ & $\mathbf{6 0 \%}$ & $\mathbf{5 0 \%}$ \\
\hline Size of zone & $15 \mathrm{~mm}$ & $14 \mathrm{~mm}$ & $13 \mathrm{~mm}$ & $10 \mathrm{~mm}$ & $7 \mathrm{~mm}$ & $7 \mathrm{~mm}$ \\
Ginger Conc & $\mathbf{1 0 0 \%}$ & $\mathbf{9 0 \%}$ & $\mathbf{8 0 \%}$ & $\mathbf{7 0 \%}$ & $\mathbf{6 0 \%}$ & $\mathbf{5 0 \%}$ \\
Size of zone & $7 \mathrm{~mm}$ & $7 \mathrm{~mm}$ & $7 \mathrm{~mm}$ & $7 \mathrm{~mm}$ & $7 \mathrm{~mm}$ & $7 \mathrm{~mm}$ \\
\hline
\end{tabular}

\section{Discussion}

Natural products including spices have been used for years because of their therapeutic and antimicrobial properties. The purpose of this project was to investigate the antimicrobial properties of two of such spices, onion and ginger.

The experiment was conducted in two stages, the preliminary and final stage, the result for the former were not recorded in the previous chapter due to irregularities and numerous errors resulting from improper aseptic technique during the extraction of the spices which lead to cross contamination and unreasonable results.

The result of this experiment showed Staphylococcus aureus to be more susceptible to Escherichia coli, which makes E.coli more resistant to the spice extracts, thus confirming the first hypothesis stated earlier. Results were obtained using three techniques (MIC,MBC, Agar diffusion) based on this ginger showed little to no antimicrobial activity against either organism particularly E.coli, this was similar to the results gotten by Serthi et al.

Based on the results, the raw onion extract showed a greater antimicrobial activity against $S$.aureus with an MBC concentration of $70 \% \mathrm{v} / \mathrm{v}$ and an inhibition zone of $28 \mathrm{~mm}$ been the largest. The activity on E.coli was different as no zones of inhibition were gotten which was similar to results gotten by Onyeaba et al. ${ }^{15} 90 \% \mathrm{v} / \mathrm{v}$ concentration was shown to kill E.coli, this was unusual as the same concentration showed no zone of inhibition when re-evaluated using disc diffusion. This could be as a result of two possible lab errors, either the bacterial lawn was too thick which rendered the extract inactive or no cells were transferred from the MIC tube to the MBC plates.

In addition, the boiled spice extract showed no antimicrobial activity against either organism thus confirming the second hypothesis. This could be as a result of the high temperature which must have deactivated the active agents rendering them ineffective against both bacteria. Due to the nature of the spice extracts, the broth dilution technique was not ideal in evaluating MIC as it was difficult to identify the presence and absence of growth, this was shown extensively during the preliminary stage. As such other techniques such as agar dilution and Epislometer test should be used when dealing with the same or similar spices.

It is also important to note that the experiment was affected by various factors which include concentration of spice extracts, volume of agar, and concentration of culture and incubation times. Future studies should be conducted in a more controlled environment were these factors are constant. Also future research should observe if the phytochemicals present in spices showed synergetic or antagonistic 
properties against each other. In conclusion, each particularly phytochemical should be extracted, purified and tested individually for its antimicrobial properties.

\section{Acknowledgements}

None.

\section{Conflict of interest}

The author declares no conflict of interest.

\section{References}

1. Serthi S, Dutta A, Gupta B, et al. Antimicrobial activity of spices against isolated food borne pathogens. International Journal of Pharmacy and Pharmaceutical Sciences. 2013;5(1):260-262.

2. Erturk O. Antimicrobial and antifungal activity of ethanolic extracts from eleven spice plants. Biologia Bratislava. 2006;61(3):275-278.

3. Skrinjar M, Nemet N. Antimicrobial effects of spices and herbs essential oils. BIBLID. 2009;40:195-209.

4. Ankri S, Mirelman D. Antimicrobial properties of allicin. Microbes Infect. 1999; 1(2):125-129.

5. Park M, Bae J, Lee DS. Antibacterial activity of [10]-gingerol and [12]-gingerol isolated from ginger rhizome against periodontal bacteria. Phytother Res. 2008;22(11):1446-1449.
6. Andrews J. Determination of minimum inhibitory concentrations. Journal of Antimicrobial Chemotherapy. 2001;48(suppl 1):5-16.

7. Prescott L. Determing the level of antimicrobial activity. In Microbiology. 5th ed. Boston: Mc Graw-Hill Higher Education; 2012. 809 p.

8. Facaultaviely anaerobic gram-negative rods. In: Holt J editor. Bergey's Manuel of determinative Bacteriology. 9th ed. Baltimore, USA: Williams and Wilkins; 2000. p. 179-180.

9. Gram positive cocci. Bergey's manuel of determinative bacteriology. 9th ed. In: Holt J editor. Baltimore. USA: Williams and Wilkins; 2000. 532 p.

10. Macconkey Agar. Acumedia; 2011.

11. MR-VP Medium • MR-VP Broth 2nd ed. Difco ${ }^{\mathrm{TM}} \& \mathrm{BBL}^{\mathrm{TM}}$ Manual, USA

12. Simmons citrate agar. Acumedia; 2011

13. Mueller hinton agar. Acumedia; 2011.

14. Tryptic soy broth. Acumedia; 2010

15. Azu N, Onyeagba R. Antimicrobial properties of extracts of Allium cepa (Onions) and Zingiber officinale (Ginger) On Escherichia coli, Salmonella typhi and Bacillus subtilis. Internet Scientific Publications. 2006;3(2). 